\title{
Increasing Advance Care Planning in Primary Care Practices: a Multi-site Quality Improvement Initiative
}

\author{
Marie B. Sandoval, $M D^{1,2}$, John G. King, MD, $M P H^{3}$, Vicki Hart, PhD ${ }^{4}$, and Allen B. Repp, MD, $M S c^{7}$ \\ 'Department of Medicine, The Robert Larner, MD College of Medicine at The University of Vermont, Burlington, USA; ${ }^{2}$ Adult Primary Care-South \\ Burlington, South Burlington, VT, USA; ${ }^{3}$ Department of Family Medicine, The Robert Larner, MD College of Medicine at The University of Vermont, \\ Burlington, USA; ${ }^{4}$ Hart Dataworks LLC, Burlington, USA.
}

$\mathrm{J}$ Gen Intern Med 34(6):809-11

DOI: $10.1007 / \mathrm{s} 11606-018-4800-4$

(c) Society of General Internal Medicine 2019

\section{INTRODUCTION}

\section{Problem Description}

Advance care planning (ACP) is the process by which a patient, in consultation with their health care provider and loved ones, makes decisions about how to direct possible future health care in times of incapacity. ${ }^{1,2}$ Primary care providers (PCPs) frequently offer longitudinal care to patients across years and are well positioned to discuss ACP with their patients. $^{2-4}$ However, ACP has not been integrated into most primary care practices, and $\mathrm{ACP}$ rates among patients in many primary care practices remain suboptimal. ${ }^{5,6}$

\section{Specific Aims}

We sought to develop and implement standardized processes to address common barriers and integrate ACP into daily practice across nine primary care clinics. Our specific aim was to increase the percentage of our adult primary care patients who had an ACP form in their electronic health record (EHR).

\section{METHODS}

\section{Context}

This project was performed in the four outpatient General Internal Medicine (GIM) and five Family Medicine (FM) clinics affiliated with the University of Vermont Medical Center (UVMMC), a non-profit academic medical center. The clinic sites serve patients across urban, suburban, and rural areas and conduct approximately 150,000 patient visits annually. All sites use a single electronic health record (Epic). Daily care team huddles and pre-visit planning had been introduced prior to 2015. A community health team offered social work services to patients on a referral basis at no out-ofpocket expense.

Published online January 2, 2019

\section{Interventions}

After seeking input from clinicians across practices, the FM and GIM quality committees identified ACP as a key priority for fiscal year 2016 (October 1, 2015, to September 30, 2016). An inter-professional work group of primary care providers, staff, and administrators developed interventions targeting specific barriers to obtaining ACP forms in our clinic sites. Identified barriers to ACP completion and related interventions are described in Table 1.

\section{Measures}

The primary measure was the percentage of patients' age $\geq$ 18 years who had a completed ACP form in the EHR.

\section{Study of the Interventions}

An interrupted time series analysis was used to compare the rate of ACP form completion at the clinic site level before (October 2014-December 2015) and after (January 2016September 2016) program implementation. A Poisson regression model was used to model the count of ACP forms completed on a monthly basis, and the patient panel number was used as an offset variable to convert the outcome into a rate.

\section{Ethical Considerations}

Ethics Approval. The project received a "not research" determination from the University of Vermont Institutional Review Board.

\section{RESULTS}

In aggregate, the rate of ACP form completion was 4.16 (95\% CI 2.32, 7.46) times higher in the postimplementation period than in the pre-implementation period (Fig. 1). The number of health care agent forms printed in the clinics served as a measure of site-level protocol adoption and increased concurrently with the rollout of the protocols in January 2016 (Fig. 1). 
Table 1 Interventions to Increase Completion of Advance Care Plans

\begin{tabular}{|c|c|c|c|}
\hline Category & Barrier addressed & Intervention & Details \\
\hline Leadership & $\begin{array}{l}\text { Clinical and quality priorities did } \\
\text { not include ACP }\end{array}$ & $\begin{array}{l}\text { Establish ACP as a priority } \\
\text { across primary care practices }\end{array}$ & $\begin{array}{l}\text { Collaborative primary care inter-professional leadership } \\
\text { team identified ACP as priority area and allocated } \\
\text { resources to project }\end{array}$ \\
\hline \multirow[t]{2}{*}{$\begin{array}{l}\text { Education and } \\
\text { engagement }\end{array}$} & $\begin{array}{l}\text { Staff and clinician reticence to } \\
\text { begin ACP conversations }\end{array}$ & $\begin{array}{l}\text { Offer site-level educational } \\
\text { sessions to clinicians and staff }\end{array}$ & $\begin{array}{l}\text { Educational sessions offered at each clinic site addressing } \\
\text { the value of ACP, types of forms, and approaches to } \\
\text { engage patients }\end{array}$ \\
\hline & $\begin{array}{l}\text { Patient reluctance to begin } \mathrm{ACP} \\
\text { conversations }\end{array}$ & $\begin{array}{l}\text { Normalize ACP discussion } \\
\text { and educate patients about } \\
\text { ACP }\end{array}$ & $\begin{array}{l}\text { Introduce ACP to patients as standard clinic workflow for } \\
\text { all adult patients. Initiate discussion with identification of } \\
\text { a health care agent }\end{array}$ \\
\hline \multirow[t]{3}{*}{$\begin{array}{l}\text { Electronic health } \\
\text { record }\end{array}$} & $\begin{array}{l}\text { Unreliable workflow for capturing } \\
\text { ACP in EHR }\end{array}$ & $\begin{array}{l}\text { Standardize workflows for } \\
\text { scanning ACP forms into } \\
\text { EHR }\end{array}$ & $\begin{array}{l}\text { Clinic staff scanned forms into EHR as specific, } \\
\text { searchable form types with common location in EHR }\end{array}$ \\
\hline & $\begin{array}{l}\text { Difficulty identifying ACP forms } \\
\text { in EHR }\end{array}$ & $\begin{array}{l}\text { Develop highly visible } \\
\text { indicator of ACP in EHR }\end{array}$ & $\begin{array}{l}\text { Created flag in the banner of the electronic chart to } \\
\text { identify ACP form presence and directly link to ACP form }\end{array}$ \\
\hline & $\begin{array}{l}\text { Difficulty remembering to assess } \\
\text { for ACP completion }\end{array}$ & $\begin{array}{l}\text { Create electronic reminder if } \\
\text { ACP forms absent }\end{array}$ & $\begin{array}{l}\text { Used Health Maintenance functionality in EHR to trigger } \\
\text { alert once every } 5 \text { years if patient had no ACP form in } \\
\text { EHR }\end{array}$ \\
\hline \multirow[t]{5}{*}{ Clinic operations } & Non-standard ACP forms & $\begin{array}{l}\text { Identify standard, preferred } \\
\text { ACP forms }\end{array}$ & $\begin{array}{l}\text { Coordinated with Vermont Ethics Network to select } \\
\text { standardized ACP forms: Health Care Agent, Advance } \\
\text { Care Plan, and COLST }\end{array}$ \\
\hline & $\begin{array}{l}\text { ACP forms not readily available on } \\
\text { site }\end{array}$ & $\begin{array}{l}\text { Ensure standardized ACP } \\
\text { forms readily available }\end{array}$ & $\begin{array}{l}\text { Standardized ACP forms and educational materials placed } \\
\text { in all patient areas }\end{array}$ \\
\hline & $\begin{array}{l}\text { Difficulty identifying patients in } \\
\text { need of ACP completion at time of } \\
\text { visit }\end{array}$ & $\begin{array}{l}\text { Identify appropriate patients } \\
\text { for ACP discussion prior to } \\
\text { visit }\end{array}$ & $\begin{array}{l}\text { During pre-visit planning, rooming staff identified patients } \\
\text { without ACP forms and reviewed with providers during } \\
\text { daily huddle }\end{array}$ \\
\hline & $\begin{array}{l}\text { Potential impingement of ACP } \\
\text { completion on visit time }\end{array}$ & $\begin{array}{l}\text { Provide patients with relevant } \\
\text { materials at time of rooming }\end{array}$ & $\begin{array}{l}\text { Rooming staff gave appropriate patients ACP form and } \\
\text { educational brochure. Providers reviewed with patient } \\
\text { during visit, if needed }\end{array}$ \\
\hline & $\begin{array}{l}\text { Potential impingement of ACP on } \\
\text { visit time }\end{array}$ & $\begin{array}{l}\text { Refer patients to community } \\
\text { resources when needed }\end{array}$ & $\begin{array}{l}\text { Patients could be scheduled for a future visit with PCP or } \\
\text { a Community Health Team social worker for ACP } \\
\text { facilitation }\end{array}$ \\
\hline \multirow[t]{4}{*}{$\begin{array}{l}\text { Audit and } \\
\text { feedback }\end{array}$} & $\begin{array}{l}\text { Inconsistent adoption of protocols } \\
\text { at clinic sites }\end{array}$ & $\begin{array}{l}\text { Perform adoption audits at site } \\
\text { level }\end{array}$ & $\begin{array}{l}\text { Site administrative directors conducted periodic audits of } \\
\text { huddles and protocol adoption }\end{array}$ \\
\hline & $\begin{array}{l}\text { Baseline and ongoing performance } \\
\text { data lacking }\end{array}$ & $\begin{array}{l}\text { Create a monthly, automated } \\
\text { electronic report }\end{array}$ & $\begin{array}{l}\text { An automated report captured ACP form completion in } \\
\text { the EHR at the individual, site, and roll-up level }\end{array}$ \\
\hline & Clinicians unaware of performance & $\begin{array}{l}\text { Create an easily accessible } \\
\text { dashboard within EHR }\end{array}$ & $\begin{array}{l}\text { An automated monthly performance report was uploaded } \\
\text { to a dashboard in the EHR that could be viewed by all } \\
\text { clinicians }\end{array}$ \\
\hline & Clinicians unaware of performance & $\begin{array}{l}\text { Review performance regularly } \\
\text { with stakeholders }\end{array}$ & $\begin{array}{l}\text { Performance was discussed at quality committee and } \\
\text { faculty meetings }\end{array}$ \\
\hline Incentives & $\begin{array}{l}\text { Financial incentives not aligned } \\
\text { with ACP completion }\end{array}$ & $\begin{array}{l}\text { Provide financial incentive to } \\
\text { physicians }\end{array}$ & $\begin{array}{l}\text { ACP form completion was used as one measure for } \\
\text { variable compensation to physicians }\end{array}$ \\
\hline
\end{tabular}

ACP, advance care planning; COLST, Clinical Orders of Life Sustaining Treatment; EHR, electronic health record

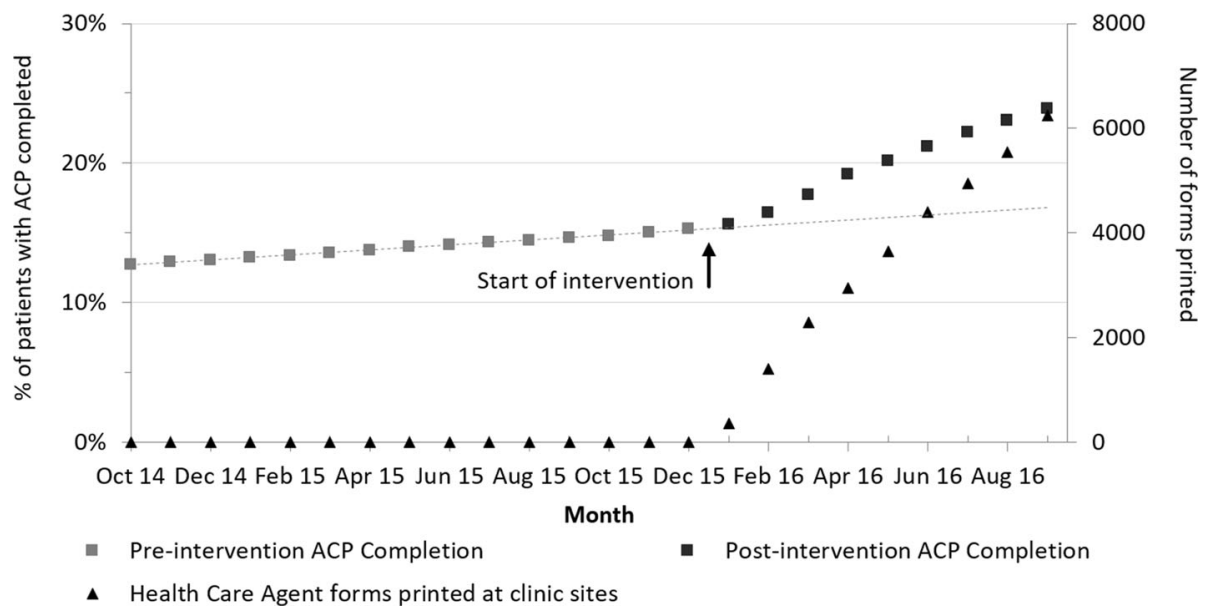

Figure 1 Advance care planning form (ACP) completion and number of health care agent forms printed during pre-intervention and postintervention periods. 


\section{DISCUSSION}

\section{Summary}

A quality initiative targeting common barriers to ACP in primary care was associated with sustained increases in the rate of ACP form completion across nine primary care clinic sites.

\section{Relevance}

Our initiative shifted ACP from a non-standard activity focused on a few patients nearing the end-of-life to a routine preventive health practice performed for all competent adult patients. In doing so, we were able to address specific perceived and actual barriers to ACP encountered by patients and health care providers and to reduce the burden of ACP on primary care providers. We speculate that the normalization of ACP as a routine part of preventive care also promoted provider and patient comfort in addressing the topic.

\section{Limitations}

We did not formally assess the adoption of our protocols at the individual level and did not distinguish between the types of ACP documents completed. Lack of infrastructure or resources might limit some clinics from replicating this work.

\section{Conclusions}

By embedding ACP into routine practice, we significantly increased the percentage of our adult primary care patients who had an ACP form in their EHR across multiple primary care sites. Long-term studies will be required to evaluate the impact of increased ACP form completion in a broad primary care population on health care utilization, patient experience, and patient and physician perceptions of goal-congruent care.

\section{Acknowledgements:}

The authors would like to acknowledge the cooperation and efforts of the participating staff, nurses, advance practice providers, physicians, administrative leaders, information technology staff, and Community Health Team members. Additionally, we sincerely appreciate the collaboration and support of the Vermont Ethics Network leadership.

Prior Presentations: We presented an earlier version of the manuscript as a plenary at the North American Primary Care Research Group (NAPCRG) conference in Montreal, Canada, on November 22, 2017, and the IPrACTISE conference in Madison, WI, USA, on April 11, 2017.

Corresponding Author: Marie B. Sandoval, MD; Adult Primary Care-South Burlington, South Burlington, VT, USA (e-mail: marie. sandoval@uvmhealth.org).

\section{Compliance with Ethical Standards:}

The project received a "not research" determination from the University of Vermont Institutional Review Board.

Conflict of Interest: The authors declare that they do not have a conflict of interest.

Publisher's Note: Springer Nature remains neutral with regard to jurisdictional claims in published maps and institutional affiliations.

\section{REFERENCES}

1. Singer PA, Martin DK, Lavery JV, Thiel EC, Kelner M, Mendelssohn DC. Reconceptualizing advance care planning from the patient's perspective. Arch Intern Med. 1998;158(8):879-84.

2. Committee on Approaching Death. Addressing key end of life issues; Institute of Medicine. Dying in America: improving quality and honoring individual preferences near the end of life. Washington (DC): National Academies Press (US); 2015.

3. Munday D, Dale J, Murray S. Choice and place of death: individual preferences, uncertainty, and the availability of care. J R Soc Med. 2007;100:211-15.

4. Michiels E, Deschepper R, Van Der Kelen G, et al. The role of general practitioners in continuity of care at the end of life: a qualitative study of terminally ill patients and their next of kin. Palliat Med. 2007;21:409-15.

5. Ramsaroop SD, Reid MC, Adelman RD. Completing an advance directive in the primary care setting: what do we need for success? J Am Geriatr Soc. 2007;55:277-83.

6. Lund S, Richardson A, May C. Barriers to advance care planning at the end of life: an explanatory systematic review of implementation studies. PLOS One. 2015;10:e0116629. 